\title{
Magnetic susceptibility application: a window onto ancient environments and climatic variations: foreword
}

\author{
A. C. DA SILVA ${ }^{1,2 *}$, M. T. WHALEN ${ }^{3}$, J. HLADIL ${ }^{4}$, L. CHADIMOVA ${ }^{4}$, D. CHEN ${ }^{5}$, \\ S. SPASSOV ${ }^{6}$, F. BOULVAIN ${ }^{1} \&$ X. DEVLEESCHOUWER ${ }^{7}$ \\ ${ }^{1}$ Pétrologie sédimentaire, B20, Allée du Six Août, 12, Université de Liège, 4000 Liège, Belgium \\ ${ }^{2}$ Paleomagnetic Laboratory, Budapestlaan 17, Utrecht University, \\ 3584 CD Utrecht, Netherlands \\ ${ }^{3}$ Deptartment of Geology and Geophysics, University of Alaska Fairbanks, \\ Faribanks, AK 99775, USA \\ ${ }^{4}$ Institute of Geology AS CR, v.v.i., Academy of Sciences, Rozvojova 269, \\ 16500 Prague 6, Czech Republic \\ ${ }^{5}$ Institute of Geology and Geophysics, Chinese Academy of Sciences, \\ \#19 Beitucheng Xilu, Chaoyang District, Beijing 100029, China \\ ${ }^{6}$ Section du Magnétisme Environnemental, Centre de Physique du Globe de l'Institut \\ Royal Météorologique de Belgique, Rue du Centre Physique, \\ 1, B-5670, Dourbes (Viroinval), Belgium \\ ${ }^{7}$ Université Libre de Bruxelles CP160/02, Département des Sciences de la Terre et de \\ l'Environnement (DSTE), Laboratoire de Sédimentologie et de Géodynamique \\ des Bassins, 50 Avenue F.D. Roosevelt, 1050 Bruxelles, Belgium \\ *Corresponding author: (e-mail: ac.dasilva@ulg.ac.be)
}

\begin{abstract}
Magnetic susceptibility (MS) is a powerful tool, which is being applied increasingly on sedimentary rocks to constrain stratigraphic correlations, or as a palaeo-environmental or palaeoclimatic tool. The origin of the magnetic minerals responsible for the variations in MS can be linked to various phenomena such as detrital inputs, pedogenesis, bacterial precipitation or diagenesis. Therefore, it is critical to improve our knowledge of the origin of the MS signal in order to apply it for correlations or as a proxy. Here, we present a synthesis of the techniques that can be applied to get a better understanding of the origin of the MS signal, through comparison with other palaeo-environmental proxies, through magnetic measurements or through dissolution and direct observation of the extracted minerals. We also propose an overview of the different techniques applied in order to use MS as a correlation tool, and we show various examples of successful applications of MS as a recorder of change in past sea-level and climate. We also present the main results and activities of the IGCP-580 project 'Application of magnetic susceptibility as a palaeoclimatic proxy on Palaeozoic sedimentary rocks and characterization of the magnetic signal'.
\end{abstract}

Understanding palaeo-environment changes, including changes in climate, requires identification of reliable proxies that can be efficiently documented within a short time frame and at relatively low cost, in order to obtain the types of high-resolution time series data required for such research. Magnetic susceptibility (MS) measurements readily meet these criteria. MS records commonly are relatively robust and can be correlated within and between different sedimentary basins. MS measurements are bulk, non-oriented measurements, and represent the sum of all individual susceptibility contributions of various magnetic minerals present in the sample. The origin of these main magnetic minerals is generally assumed to result from detrital inputs, from fluvial or aeolian sources (Ellwood et al. 2000; Stage 2001; Rey et al. 2008; Hladil et al. 2010a; Maher 2011). In some case, magnetic minerals are also related to soil formation (Tite \& Linington 1975; Dearing et al. 1996) or are of bacterial origin (Kirschvink \& Chang 1984; Hladil et al. 2004; Kopp \& Kirschvink 2008). In Quaternary marine

From: Da Silva, A. C., Whalen, M. T., Hladil, J., Chadimova, L., Chen, D., Spassov, S., Boulvain, F. \& Devleeschouwer, X. (eds) 2015. Magnetic Susceptibility Application: A Window onto Ancient Environments and Climatic Variations. Geological Society, London, Special Publications, 414, 1-13.

First published online June 24, 2015, http://doi.org/10.1144/SP414.12

(C) 2015 The Author(s). Published by The Geological Society of London. All rights reserved.

For permissions: http://www.geolsoc.org.uk/permissions. Publishing disclaimer: www.geolsoc.org.uk/pub_ethics 
sediments, magnetofossils are locally relatively common, compared with the pre-Quaternary magnetofossil records (Kopp \& Kirschvink 2008).

The use of MS as stratigraphic tool was originally developed during the 1970s, with studies on Mesozoic and Cenozoic deep-marine (Radhakrishnamurty et al. 1968; Amin et al. 1972) and lake sediments (Oldfield et al. 1978). The climatic influence on the MS evolution was comprehensively documented in Pleistocene marine sediments, through the link between MS and oxygen isotope evolution (Robinson 1986). In this respect, MS was used for correlation and as a palaeo-environmental proxy (e.g. Foubert \& Henriet 2009). Furthermore, spectral analysis of MS records was also used to demonstrate the presence of orbitally driven climatic cycles in Cenozoic sediments (Mead \& Tauxe 1986; Shackleton et al. 1999), which significantly improved the precision of the Cenozoic Time Scale (Hinnov \& Hilgen 2012). More recently, the use of MS has been widespread in the analysis of lithified Palaeozoic (mostly marine) sedimentary rocks (Crick et al. 1997; Da Silva \& Boulvain 2002; Racki et al. 2002; Hladil et al. 2006; Da Silva et al. 2009a; Whalen \& Day 2010; Koptíková 2011). However, deciphering the ultimate origin of the magnetic minerals carrying the MS signal is of crucial importance for meaningful interpretation of the MS signal in terms of palaeo-environmental evolution. In lithified sediments, the primary origin of the magnetic minerals is often partly constrained. Key questions that need to be considered include: what the source of the primary minerals is; and whether they are of aeolian or riverine sources or formed during pedogenesis or by bacteria. Furthermore, secondary processes, such as diagenesis, remagnetization and metamorphism, can influence, complicate or completely erase the primary signal.

This Special Publication was initiated to gather and present results from the IGCP-580 UNESCO project (2009-2015) on the 'Application of magnetic susceptibility as a palaeo-climatic proxy on Palaeozoic sedimentary rocks and characterization of the magnetic signal'. The volume includes contributions related to MS data from Silurian rocks to Recent sediments, with material from Europe, Middle East, North Africa, China, North America and Russia. The book is divided in three parts: the first part concerns the control exerted by sedimentary setting on MS evolution; the second part comprises contributions that focus on the origin and nature of the minerals carrying the MS signal; and the final part deals with the identification of climatic/ astronomic cycles in magnetic susceptibility signals.

In this introductory paper, we will present the different techniques that can be applied in order to identify the nature and the origin of the magnetic minerals, with examples for each technique. We then present some examples of the application of MS, including methods and precautions for correlations and palaeo-environmental and palaeoclimatic applications. Some of the techniques and applications described in this introduction are used in papers included in this volume (given in bold at first mention). The main results and activities of the IGCP-580 project are also described.

\section{Origin of the MS signal}

Since the MS signal can be related to primary origins (mostly fluvial or aeolian detrital inputs, bacterial or pedogenetic precipitation) or can be transformed through secondary processes (diagenesis, remagnetization, metamorphism), it is important to assess the origin of the minerals carrying the MS signal. Demonstration of a primary detrital origin of the magnetic component is indeed crucial in order to effectively use MS for correlations or as a palaeoenvironmental and palaeo-climatic proxy.

Different techniques have been developed in order to assess the origin of minerals that influence the MS signal including: (1) comparison with other proxies influenced by palaeo-environmental parameters; (2) magnetic property measurements to obtain information on the magnetic mineralogy and grain size; and (3) direct observation of the magnetic minerals via dissolution.

\section{Comparison with other proxies}

Comparing the MS signal with other palaeoenvironmental proxies or detrital proxies permits inferences about the carriers of the MS signal. A positive correlation between MS and independent palaeo-environmental proxies is the first indication that the primary signal is preserved. These non-magnetic palaeo-environmental proxies include the following:

- Clay or quartz content or insoluble residues in carbonate rocks are typically of detrital origin and are classical parameters to be compared with MS in order to infer a primary, detrital origin of the MS signal (Ellwood et al. 1999; English 1999; Mabille \& Boulvain 2008; Hladil et al. 2009). For example, Mabille \& Boulvain (2008) showed that the MS increased with increasing quartz content on two Middle Devonian sections from Belgium (Fig. 1a).

- Geochemical elements such as $\mathrm{Zr}, \mathrm{Th}, \mathrm{Ti}$ and $\mathrm{Al}$ are proxies for changes in source or amount of detrital material or type of weathering (Tribovillard et al. 2006; Calvert \& Pedersen 2007) and have been compared with MS in order to highlight a detrital origin of this MS signal (Riquier et al. 2010; Da Silva et al. 2012, 2013; Śliwiński 


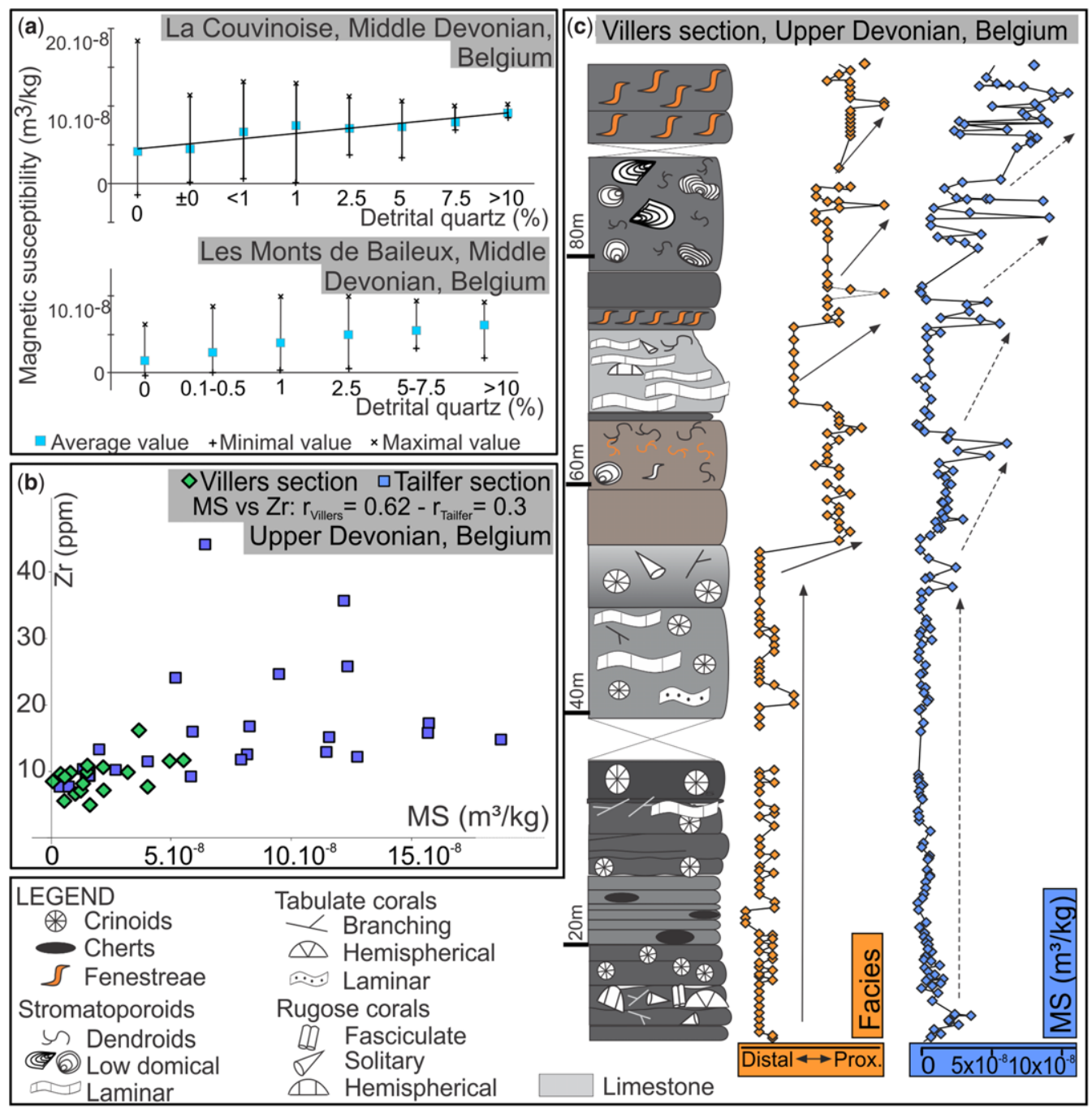

Fig. 1. Comparison of magnetic susceptibility signal with other proxies and magnetic parameters from selected Devonian examples. (a) Average, minimal and maximal magnetic susceptibility values plotted by percentage of detrital quartz for La Couvinoise and Les Monts de Baileux sections from Belgium; Modified after Mabille \& Boulvain (2007). (b) Magnetic susceptibility compared with $\mathrm{Zr}$ content in Villers and Tailfer sections from Belgium, modified from Da Silva et al. (2013). (c) Comparison of magnetic susceptibility evolution with sedimentary facies from the Villers section (Belgium). Modified after Da Silva et al. (2013).

et al. 2012; Alekseev et al. 2015; Grabowski et al. 2015; Jadot \& Boulvain 2015; Pas et al. 2015; Whalen et al. 2015). An example is provided in Figure $1 b$, with a comparison of the MS with the $\mathrm{Zr}$ content for two Frasnian sections from Belgium (Da Silva et al. 2012). The two sections illustrate very different behaviours, with the Villers section indicating a moderate correlation between MS and $\mathrm{Zr}$ content $(r=0.6)$ and a poor correlation on the Tailfer section $(r=0.3)$. This suggests that some primary signal was partly preserved in the Villers section, while it was very poorly preserved owing to diagenetic impact at Tailfer (for complete results, see Da Silva et al. 2013).

- Gamma-ray spectrometry (GRS) measurements are related to the abundance of the three dominant radioactive elements occurring in sedimentary rocks: K, Th and U. For carbonate rocks, K and $\mathrm{Th}$ are interpreted as reflecting clastic 
content, whereas $\mathrm{U}$ is related to bottom-water oxygenation and diagenetic processes involving changes in oxidation-reduction state (Ehrenberg \& Svana 2001; Kozłowski \& Sobień 2012). GRS curves have often been compared with MS patterns, and differences and similarities can provide insight into detrital and/or diagenetic influences (Bábek et al. 2010; Koptíková et al. 2010a, b, Koptíková 2011; Kozłowski \& Sobień 2012; Ellwood et al. 2013; Grabowski et al.
2013; Chadimova et al. 2015; Devleeschouwer et al. 2015; Mayrhofer \& Lukeneder 2015). In Devonian carbonates from the Barrandian area in the Czech Republic (Požáry-3 section), Koptíková et al. (2010a) showed that there is a relatively good correlation between MS and GRS (Fig. 2).

- The spectral reflectance (SR)/colour index is used as indicator of $\mathrm{CaCO}_{3}$ content and organic carbon in carbonates and is interpreted in terms

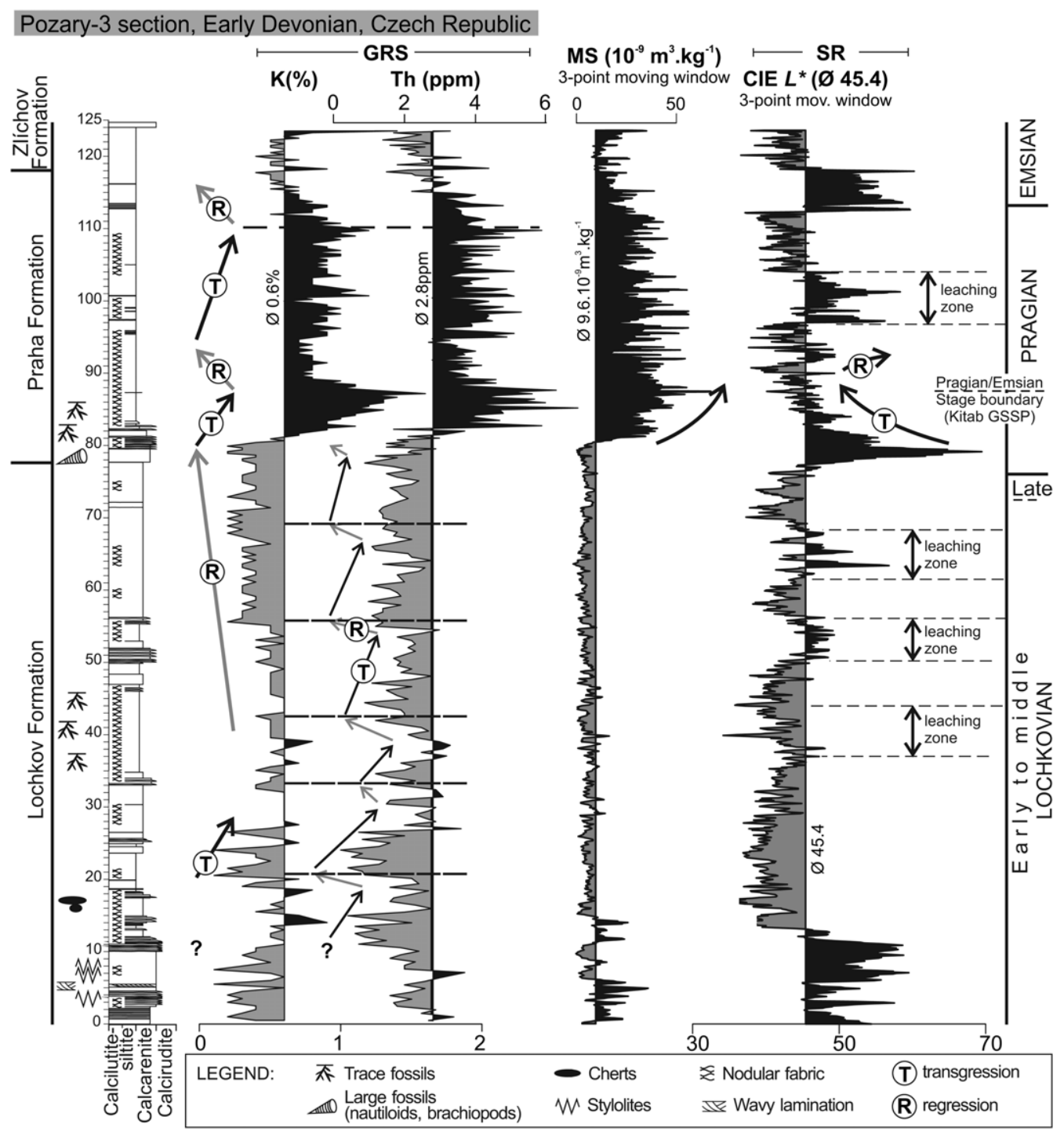

Fig. 2. Stratigraphic framework of the Požáry-3 section: lithostratigraphy, chronostratigraphy and basic outcrop logging patterns - spectral gamma-ray logs (GRS), magnetic susceptibility log (MS), spectral reflectance (SR) and brightness (CIE $L^{*}$, the brightness, is a dimensionless number (no units), as it is defined as a ratio between the maximum reflectance or white colour and the measured value). Modified after Koptíková et al. (2010a). 
of cyclicity and palaeo-climate. The SR allows an estimation of the concentration of minerals such as hematite, goethite and chlorites, which are often interpreted as palaeo-climatic proxies (e.g. Koptíková et al. 2010a). Comparison of MS signal with SR was proposed in Koptíková et al. (2010a), and Devleeschouwer et al. (2015). Koptíková et al. (2010a) also showed that both SR and MS signals, in Czech Barrandian Devonian carbonates, record a marked cyclicity (Fig. 2, Požáry-3 section). The SR $\log$ is obscured by zones of elevated brightness, which are associated with minor faults and 'leaching zones' (Fig. 2) with enhanced diagenesis. However, the MS signal in these zones remains relatively unaffected (Fig. 2), which indicates that in this case, local diagenetic alteration has a low impact on the MS data.

- Facies evolution can also be compared with the MS signal to identify a link between sea-level and MS changes (Mabille et al. 2008; Da Silva et al. 2009a; Bábek et al. 2013; Alekseev et al. 2015; Dechamps et al. 2015; Grabowski et al. 2015; Sardar Abadi et al. 2015). The MS signal from the Villers section (Devonian, Belgium), which was previously interpreted as carrying a detrital signal, based on the link with $\mathrm{Zr}$ (Fig. 1b), also demonstrates a clear link between MS and facies evolution, with increasing MS correlated with shallowing-upward trends (Fig. 1c; Da Silva et al. 2012).

- Radioactive isotopes: Sr (Frank 2002) and Nd isotopes (Burton \& Vance 2000; Burton 2006; Dopieralska et al. 2006) are derived from the weathering of continental material and submarine volcanism, and can be used to investigate continental erosion and oceanic circulation. Application of $\mathrm{Sr}$ or $\mathrm{Nd}$ isotopes on Palaeozoic sections is still relatively rare and, to our knowledge, no comparison with MS signal has been published yet.

\section{Magnetic property measurements}

Magnetic property measurements allow identification of the nature, amount and grain size of the main magnetic minerals. Magnetic grain size is a key parameter because it depends strongly on the forming conditions of the magnetic minerals: diagenetic grains are typically $30-100 \mathrm{~nm}$ whereas detrital grains are commonly much coarser (micron size) (Channel \& McCabe 1994). Numerous books have offered extended details on all of these techniques (e.g. Walden et al. 1999; Evans \& Heller 2003; Tauxe 2010). Here we propose a synthesis of the main magnetic techniques and significant outcomes for the application of MS as a palaeoenvironmental tool.

\section{Nature of the magnetic minerals}

(1) Hysteresis measurements allow the quantification of the proportion of ferromagnetic (e.g. magnetite, hematite, goethite, etc.) minerals on one side and of paramagnetic (e.g. most clay minerals, pyrite, etc.) and diamagnetic (e.g. calcite, quartz, etc.) minerals on the other side (Devleeschouwer et al. 2010; Riquier et al. 2010; Da Silva et al. 2013; Blumentritt 2015; Devleeschouwer et al. 2015; Sardar Abadi et al. 2015). Furthermore, parameters extracted from hysteresis loops (parameters such as: $M_{\mathrm{rs}}$, remanence magnetization; $M \mathrm{~s}$, saturation magnetization; $H_{\mathrm{c}}$, coercivity; and $H_{\text {cr }}$, remanence coercivity) permit a rough discrimination between high (such as hematite) and low coercivity (such as magnetite) ferromagnetic minerals and provide information on the grain size (see below).

(2) The isothermal remanent magnetization (IRM) acquisition curve and S-ratio allow a better discrimination of low and high coercivity ferromagnetic minerals by Gaussian function processing (Robertson \& France 1994; Kruiver et al. 2001; Egli 2003), which also provides an estimate of their relative proportions (applied by e.g. Egli 2004; Font et al. 2005, 2010; Da Silva et al. 2013; Chadimova et al. 2015; Devleeschouwer et al. 2015; Grabowski et al. 2015).

(3) Thermomagnetic measurements facilitate identification of the ferromagnetic mineral types based on their respective Curie or Néel temperature, but cannot provide quantification of these minerals (e.g. Nawrocki et al. 2008; Devleeschouwer et al. 2010; Ellwood et al. 2015).

\section{Magnetic grain size indicators}

(1) The Day plot (defined by Day et al. 1977, and improved by Parry 1982, and Dunlop 2002) uses the main hysteresis parameters in an $M_{\mathrm{s}} / M_{\mathrm{rs}}$ v. $H_{\mathrm{c}} / H_{\mathrm{cr}}$ plot (applied by Devleeschouwer et al. 2010; Riquier et al. 2010; Casier et al. 2011; Sardar Abadi et al. 2015), in order to discriminate between domain state (from the smallest grains to the coarsest: superparamagnetic, SP; single domain, SD; pseudo-single-domain, PSD; multidomain, $\mathrm{MD})$.

(2) The squareness v. coercivity plot (Tauxe et al. 2002) uses hysteresis parameters in an $M_{\mathrm{s}} / M_{\mathrm{rs}}$ v. $H_{\mathrm{c}}$ plot that is also applied to discriminate between domain state (applied by Da Silva et al. 2012, 2013; Devleeschouwer et al. 2015).

(3) The frequency dependence of susceptibility $\left(\chi_{\mathrm{fd}}\right)$ is the difference in susceptibility 
measured at high and low frequencies and is used to identify the presence of SP particles (Jackson et al. 1993; Font et al. 2005; Chadimova et al. 2015; Devleeschouwer et al. 2015).

(4) Anhysteresic remanent magnetization susceptibility $\left(\chi_{\mathrm{ARM}}\right)$ is used in order to identify SD particles (Evans \& Heller 2003; Blumentritt 2015; Chadimova et al. 2015; Grabowski et al. 2015).

(5) The anhysteresic remanent magnetization divided by the isothermal remanent magnetization (ARM/IRM), the saturation isothermal remanent magnetization divided by the low field susceptibility (SIRM $/ \chi_{\mathrm{lf}}$ ) and the $\chi_{\mathrm{ARM}} / \chi_{\mathrm{lf}}$ ratio are also grain size indicators (Evans \& Heller 2003);

(6) First-order reversal curves (Roberts et al. 2000) are used for magnetic characterization of different populations of magnetite (Roberts et al. 2006) or biogenic magnetite SD particles (Egli et al. 2010);

(7) The decay of viscous remanent magnetization (Mullins \& Tite 1973; Spassov \& Valet 2012) indicates the presence of ultra-fine-grained particles (close to the limits between SP and $\mathrm{SD}$ grain sizes, i.e. around $30 \mathrm{~nm}$ ). Nevertheless, this parameter is influenced by the lithology (e.g. difference between clastic and carbonate sediments; Zwing et al. 2005) and probably by changes in the concentration or in the grain size population of these nanomagnetic particles.

\section{Direct observations of the magnetic minerals}

Direct examination of magnetic grains from a sample is possible when the grains are abundant and large enough. However, it is often necessary to extract the magnetic minerals from the rock. Such processing is extremely time-consuming (full procedure by Hounslow \& Maher 1999), but it may be the only procedure providing precise information about the origin of the magnetic minerals. Figure 3 illustrates iron oxide and pyrrhotite grains extracted from Devonian carbonates (from Koptíková et al. 2010b; Koptíková 2011).

\section{Applications of MS: a window onto ancient palaeo-environments}

After deciphering the origin of the MS signals through one of the previously described techniques, or even better, a combination of different techniques, it is possible to isolate the primary, detrital MS signal. Such MS data, forming long, continuous time series, can then be used as a palaeoenvironmental and palaeo-climatic proxy and for correlations and cyclostratigraphic analyses.

\section{Application of MS as a correlation tool}

After the pioneering works of Crick et al. (1997), MS has been widely used for correlating Palaeozoic sedimentary sequences. Importantly, these correlations need to be framed in a well-developed biostratigraphic framework. Correlations can then be established through different techniques:

- By visual correlation of MS peaks (Crick et al. 1997; Geršl \& Hladil 2004; Da Silva \& Boulvain 2006; Bábek et al. 2010; Boulvain et al. 2010; Michel et al. 2010; Dechamps et al. 2015; Grabowski et al. 2015; Mayrhofer \& Lukeneder 2015; Whalen et al. 2015).

- The MS curve can also be included in a sequence stratigraphic framework (Whalen \& Day 2008, 2010; Da Silva et al. 2010). Whalen \& Day (2010) demonstrated a predictable pattern of relatively low MS in late transgressive and early highstand facies and higher MS in late highstand, lowstand and early transgressive facies at both the sequence and parasequence level.
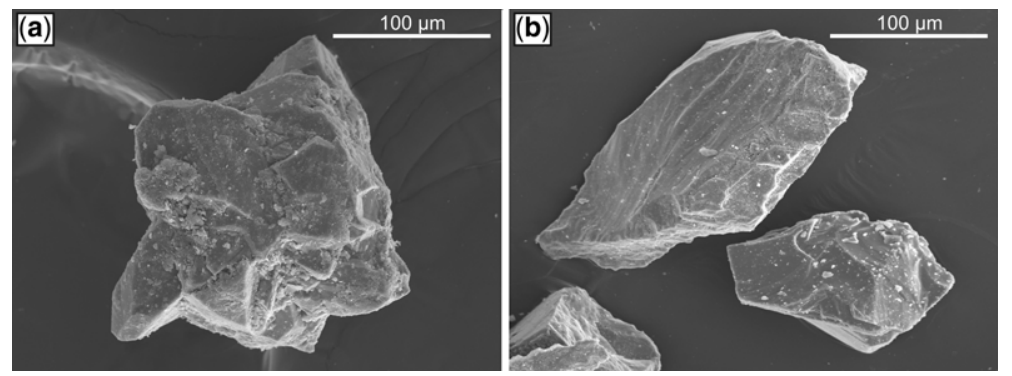

Fig. 3. SEM images of mineral assemblages in insoluble residues from Devonian. (a) Iron oxide, Eifelian in the Prague Synform, from the Cerveny lom Quarry. (b) Pyrrhotite, Lochkovian to Emsian in the Prague Synfrom, Požáry-3 section (79.7 m, see log on Fig. 2), modified after Koptíková et al. (2010b). 
- Ellwood et al. (2006) presented the MS curve as bar-log format, similar to the presentation of magnetic polarity data. If the MS cyclic trends increase or decrease by a factor of 2 or more, and if the change is represented by two or more data points, then this change is assumed to be significant, and the highs and lows associated with these cycles are differentiated by filled (high MS values) or open (low MS values) bar logs. Whalen \& Day (2010), using bar logs delineated from spline-smoothed MS signals, demonstrated very high-level correlation $\left(R^{2} \geq 0.9\right)$ of the MS signature between several sections in western Canada through a modified graphic correlation technique.

- Hladil et al. (2010b) applied the numerical method of dynamic time warping (developed in the field of speech recognition), which computes the most probable correlation(s). This technique is proposed to solve inherent problems related to MS records, such as patterns with different shapes and intensities and the possible incompleteness of the record from individual sections. Chadimova et al. (2015) applied dynamic time warping to a Silurian succession in the Czech Republic.

- After identifying Milankovich cycles (see more details in the following section) in target sections, De Vleeschouwer et al. (2015) and De Vleeschouwer et al. (2012b), used these as correlation anchors in order to correlate respectively Givetian and Frasnian sections. The construction of a floating time scale permits display of the data as time series in the time domain, rather than in the distance domain. It is then possible to correlate contemporaneous series, since accumulation rate does not have to be taken into account (see also Da Silva et al. 2013).

\section{Application of MS records as palaeo- environmental and palaeo-climatic proxy}

Influence of sea-level. If magnetic minerals are of a primary detrital origin, the MS signal may be strongly influenced by sea-level variations. Ellwood et al. (1999) contend that, during times of regression, the base level is lowered, which increases erosion potential, thus increasing the amount of detrital particles transported and distributed into the marine setting. This would cause enhanced MS values during times of low or falling sea-level. In this respect, MS has been often interpreted as influenced by sea-level variations (Zhang et al. 2000; Da Silva et al. 2009a, b; Koptíková et al. 2010a; Whalen \& Day 2010). The relationships documented by Whalen \& Day (2010) largely support prior assertions about the relationship of MS to sea-level change (Crick et al. 1997; Ellwood et al. 1999,
2000) at the third and fourth order but not during a long-term second-order sea-level event. Therefore, the link between sea-level changes and MS may be more complicated than expected (Mabille et al. 2008; Da Silva et al. 2009a; Bábek et al. 2013). Actually, the record of sea-level changes may differ depending on the sedimentary setting and the morphology of carbonate platforms, which can influence the way magnetic minerals settle in a sedimentary environment (cf. comparison of MS records on different platform types in Da Silva et al. 2009a). On carbonate platform (s.s.), during lowering sealevel, the carbonate production rate decreases, while the detrital input increases, leading to higher MS values (Da Silva et al. 2009a). On carbonate ramp and atoll settings, higher sedimentation rate and water agitation in shallow water facies can hamper the settling of magnetic particles and can result in lower MS values (Mabille \& Boulvain 2007; Da Silva et al. 2009a, b; Bábek et al. 2010, 2013; Koptíková et al. 2010a). These findings demonstrate the importance of understanding the depositional setting of facies sampled for MS and the potential pitfalls of comparing MS records from different palaeo-environments (see also Alekseev et al. 2015; Grabowski et al. 2015; Pas et al. 2015; Sardar Abadi et al. 2015).

Influence of climate - cyclostratigraphy. As mentioned above the influence of climate on MS variations in sediments was demonstrated in Pleistocene sediments by coupling variations in MS with the O-isotope curve (Robinson 1986). In Palaeozoic sediments, this influence is often inferred, and the recent application of spectral analysis on MS records provides convincing evidence of the presence of astronomically driven (Milankovich) cycles in Palaeozoic sections (Rodionov et al. 2003; Ellwood et al. 2008, 2011a, b, 2015; De Vleeschouwer et al. 2012a, b, 2015; Da Silva et al. 2013; Devleeschouwer et al. 2015; Grabowski et al. 2015). Identification and counting of climatic cycles of constant duration, identified into MS signals, permit the creation of floating time scales for some parts of the Palaeozoic (Ellwood et al. 2007, 2011a, b, 2015; De Vleeschouwer et al. 2012a, b, 2015; García-Alcalde et al. 2012; Da Silva et al. 2013). These floating time scales improve our knowledge of the timing of different events (De Vleeschouwer et al. 2013), further providing more accurate correlations between different sedimentological sections (see also the previous section). The average spectral misfits method (Meyers \& Sageman 2007) can be applied to MS datasets and allows a quantification of the optimal sedimentary rate for a stratigraphic interval (when a orbital signal is preserved). It also provides a statistical test for the rejection of the null hypothesis, that is, no orbital signal. 


\section{IGCP-580 project: application of MS as a palaeo-environmental tool}

The IGCP-580 project (UNESCO) entitled 'Application of magnetic susceptibility as a palaeoclimatic proxy on Palaeozoic sedimentary rocks and characterization of the magnetic signal' (synthesis of project activities in Da Silva et al. 2014) was initiated to encourage the use of MS data for correlation and palaeo-environmental/palaeoclimatic analysis in deep time. It was launched in 2009 within the framework of the development and acquisition and processing of MS data from Palaeozoic rocks, but also with an awareness of the possible complexity behind this MS signal and the importance of gaining a better understanding of its origin.

The first main objective of IGCP-580 was to compile existing MS data and to collect new material and MS data (about 35000 samples collected by the different participating teams during the 5 years of the project). During the project, we received all types of contribution related to the application of MS, in all types of setting and lithology and from any time period. However, in order to provide an over-arching framework, we decided to focus the IGCP-580 field work and sampling on the Devonian system. This time period was selected because, for the Palaeozoic, it has a relatively robust biostratigraphic framework, allowing an essential control to frame the correlations through MS. Furthermore, an important amount of MS data had already been published on the Mid-Palaeozoic (Crick et al. 2001; Ellwood et al. 2001, 2007; Da Silva \& Boulvain 2002, 2003, 2006; Hladil 2002; Racki et al. 2002; Hladil et al. 2003, 2006; Geršl \& Hladil 2004; Whalen \& Day 2008; Da Silva et al. 2009b). This permitted insertion of the newly collected material (Devonian from the Czech Republic, China, Carnic Alps and Canada; see Da Silva et al. 2014) into an already extensive database.

This book and introductory chapter are a contribution to the IGCP-580 (UNESCO) project: Application of magnetic susceptibility as a palaeo-climatic proxy on Palaeozoic sedimentary rocks and characterization of the magnetic signal.

\section{References}

Alekseev, A. O., Kabanov, P. B., Alekseeva, T. V. \& Kalinin, P. 2015. Magnetic susceptibility and geochemical characterization of an upper Mississippian cyclothemic section Polotnyanyi Zavod, (Moscow Basin, Russia). In: Da Silva, A. C., Whalen, M. T. ET AL. (eds) Magnetic Susceptibility Application - A Window onto Ancient Environments and Climatic Variations. Geological Society, London, Special
Publications, 414. First published online January 26, 2015, http://doi.org/10.1144/SP414.1

Amin, B. S., Likhite, S. D., RadHakrishnamurty, C. \& Somayajulu, B. L. K. 1972. Susceptibility stratigraphy and paleomagnetism of some deep Pacific Ocean cores. Deep-Sea Research and Oceanographic Abstracts, 19, 249-252.

Bábek, O., Kalvoda, J., Aretz, M., Cossey, P. J., Devuyst, F. X., Herbig, H. G. \& Sevastopulo, G. 2010. The correlation potential of magnetic susceptiblility and outcrop Gamma-Ray logs at TournaisianViséan boundary sections in Western Europe. In: DA Silva, A. C. \& Boulvain, F. (eds) Magnetic Susceptibility, Correlations and Palaeozoic Environments. Geologica Belgica, Brussels, 13, 291-308.

BábeK, O., Kalvoda, J., Cossey, P., ŠimíčeK, D., Devuyst, F.-X. \& Hargreaves, S. 2013. Facies and petrophysical signature of the Tournaisian/Viséan (Lower Carboniferous) sea-level cycle in carbonate ramp to basinal settings of the Wales-Brabant massif, British Isles. Sedimentary Geology, 284-285, 197-213.

Blumentritt, D. J. \& Lascu, I. 2015. A comparison of magnetic susceptibility measurement techniques and ferrimagnetic component analysis from recent sediments in Lake Pepin (USA). In: DA Silva, A. C., Whalen, M. T. et al. (eds) Magnetic Susceptibility Application - A Window onto Ancient Environments and Climatic Variations. Geological Society, London, Special Publications, 414. First published online November 19, 2014, http://doi.org/10.1144/ SP414.6

Boulvain, F., Da Silva, A. C., Mabille, C., Hadil, J., Gersl, M., Koptikova, L. \& Schnabl, P. 2010. Magnetic susceptibility correlation of km-thick EifelianFrasnian sections (Ardenne-Moravian karst). In: DA Silva, A. C. \& Boulvain, F. (eds) Magnetic Susceptibility, Correlations and Palaeozoic Environments. Geologica Belgica, 13, 309-318.

Burton, K. W. 2006. Global weathering variations inferred from marine radiogenic isotope records. Journal of Geochemical Exploration, 88, 262-265.

Burton, K. W. \& VAnCE, D. 2000. Glacial-interglacial variations in the neodymium isotope composition of seawater in the Bay of Bengal recorded by planktonic foraminifera. Earth and Planetary Science Letters, 176, 425-441.

Calvert, S. E. \& Pedersen, T. F. 2007. Elemental proxies for palaeoclimatic and palaeoceanographic variability in marine sediments: interpretation and application. In: Claude, H. M. \& AnNe De, V. (eds) Developments in Marine Geology. Elsevier, Oxford, 1, 567-644.

Casier, J. G., Devleeschouwer, X., Petitclerc, E. \& PrÉAt, A. 2011. Ostracods, rock facies and magnetic susceptibility of the Hanonet Formation/TroisFontaines Formation boundary interval (Early Givetian) at the Mont d'Haurs (Givet, France). Bulletin de l'Institut Royal des Sciences Naturelles de Belgique, 81, 63-96.

Chadimova, L., Vacek, F., Sobien, K., Slavik, L. \& HLADIL, J. 2015. Petrophysical record of the Late Silurian shallow-water carbonate facies across the Lau Event (Prague Synform, Czech Republic) and 
dynamic time warping alignment of the magnetic susceptibility logs. In: Da Silva, A. C., Whalen, M. T. ET AL. (eds) Magnetic Susceptibility Application - A Window onto Ancient Environments and Climatic Variations. Geological Society, London, Special Publications, 414. First published online June 15, 2015, http://doi.org/10.1144/SP414.14

Channel, J. E. T. \& McCABE, C. 1994. Comparison of magnetic hysteresis parameters of unremagnetized and remagnetized limestones. Journal of Geophysical Research, 99, 4613-4623.

Crick, R. E., Ellwood, B. B., El Hassani, A., Feist, R. \& HLADIL, J. 1997. Magnetosusceptibility event and cyclostratigraphy (MSEC) of the Eifelian-Givetian GSSP and associated boudary sequences in north Africa and Europe. Episodes, 20, 167-175.

Crick, R. E., Ellwood, B. B., Hladil, J., El Hassani, A., Hrouda, F. \& Chlupac, I. 2001. Magnetostratigraphy susceptibility of the Pridolian-Lochkovian (SilurianDevonian) GSSP (Klonk, Czech Republic) and coeval sequence in Anti-Atlas Morocco. Palaeogeography, Palaeoclimatology, Palaeoecology, 167, 73-100.

Da Silva, A. C. \& Boulvain, F. 2002. Sedimentology, magnetic susceptibility and isotopes of a Middle Frasnian Carbonate platform: Tailfer section, Belgium. Facies, 46, 89-102.

Da Silva, A. C. \& Boulvain, F. 2003. Sedimentology, magnetic susceptibility and correlations of Middle Frasnian platform limestone (Tailfer and Aywaille sections, Belgium). Geologica Belgica, 6, 81-96.

Da Silva, A. C. \& Boulvain, F. 2006. Upper Devonian carbonate platform correlations and sea level variations recorded in magnetic susceptibility. Palaeogeography, Palaeoclimatology, Palaeoecology, 240, 373-388.

Da Silva, A. C., Mabille, C. \& Boulvain, F. $2009 a$. Influence of sedimentary setting on the use of magnetic susceptibility: examples from the Devonian of Belgium. Sedimentology, 56, 1292-1306.

Da Silva, A. C., Potma, K., Weissenberger, J. A. W., Whalen, M. T., Mabille, C. \& Boulvain, F. $2009 \mathrm{~b}$. Magnetic susceptibility evolution and sedimentary environments on carbonate platform sediments and atolls, comparison of the Frasnian from Belgium and from Alberta. Sedimentary Geology, 214, 3-18.

Da Silva, A. C., Yans, J. \& Boulvain, F. 2010. EarlyMiddle Frasnian (Early Late Devonian) sedimentology and magnetic susceptibiliy of the Ardenne area (Belgium): identification of severe and rapid sea level fluctuations. In: DA Silva, A. C. \& Boulvain, F. (eds) Magnetic Susceptibility, Correlations and Palaeozoic Environments. Geologica Belgica, Brussels, 13, 319-332.

Da Silva, A. C., DekKers, M. J., Mabille, C. \& BoulVAIN, F. 2012. Magnetic signal an its relationship with paleoenvironments and diagenesis - examples from the Devonian carbonates of Belgium. Studia Geophysica \& Geodaedica, 56, 677-704.

Da Silva, A. C., De Vleeschouwer, D. et AL. 2013. Magnetic susceptibility as a high-resolution correlation tool and as a climatic proxy in Paleozoic rocks - merits and pitfalls: examples from the Devonian in Belgium. Review paper. Marine and Petroleum Geology, 46, $173-189$.
Da Silva, A. C., Whalen, M. T. et AL. 2014. Application of magnetic susceptibility as a paleoclimatic proxy on Paleozoic sedimentary rocks and characterization of the magnetic signal - IGCP-580 projects and events. Episodes, 37, 87-95.

Day, R., Fuller, M. \& Schmidt, V. A. 1977. Hysteresis propreties of titanomagnetites: grain-size and compositional dependence. Physics of the Earth and Planetary Interiors, 13, 260-267.

Dearing, J. A., Hay, K. L., Baban, S. M. J., HuddleSton, A. S., Wellington, E. M. H. \& Loveland, P. J. 1996. Magnetic susceptibility of soil: an evaluation of conflicting theories using a national data set. Geophysical Journal International, 127, 728-734.

Dechamps, S., Boulvain, F. \& Da Silva, A. C. 2015. Magnetic susceptibility and facies relationship in Bajocian-Bathonian carbonates from the Azé caves, southeastern Paris Basin, France. In: DA Silva, A. C., Whalen, M. T. ET AL. (eds) Magnetic Susceptibility Application - A Window onto Ancient Environments and Climatic Variations. Geological Society, London, Special Publications, 414. First published online March 23, 2015, http://doi.org/10.1144/SP414.11

De Vleeschouwer, D., Da Silva, A. C., Boulvain, F., Crucifix, M. \& Claeys, P. 2012a. Precessional and half-precessional climate forcing of Mid-Devonian monsoon-like dynamics. Climate of the Past, 7, 1427-1455.

De Vleeschouwer, D., Whalen, M. T., Day, J. E. \& Claeys, P. 2012b. Cyclostratigraphic calibration of the Frasnian (Late Devonian) time-scale (Western Alberta, Canada). Geological Society of America Bulletin, 124, 928-942.

De Vleeschouwer, D., Rakocinski, M., Racki, G., Bond, D. P. G., Sobien, K. \& Claeys, P. 2013. The astronomical rhythm of Late-Devonian climate change (Kowala section, Holy Cross Mountains, Poland). Earth and Planetary Science Letters, 365, 25-37.

De Vleeschouwer, D., Boulvain, F., Da Silva, A. C., Pas, D., Labaye, C. \& Claeys, P. 2015. astronomical interpretation of the magnetic signal signal of the Givetian sections in the Dinant Synclinorium (La Couvinoise, Monts de Baileux, Fromelennes-Flohimont and La Thure). In: Da Silva, A. C., Whalen, M. T. ET AL. (eds) Magnetic Susceptibility Application - A Window onto Ancient Environments and Climatic Variations. Geological Society, London, Special Publications, 414. First published online November 21, 2014, http://doi.org/10.1144/SP414.3

Devleeschouwer, X., Petitclerc, E., Spassov, S. \& PrÉAt, A. 2010. The Givetian-Frasnian boundary at Nismes parastratotype (Belgium): the magnetic susceptibility signal controlled by ferromagnetic minerals. In: DA Silva, A. C. \& Boulvain, F. (eds) Magnetic Susceptibility, Correlations and Palaeozoic Environments. Geologica Belgica, Brussels, 13, 351-366.

Devleeschouwer, X., Riquier, L., Babek, O., De VleeShouwer, D., Petitclerc, E., Sterckx, S. \& Spassov, S. 2015. Magnetization carriers of grey to red deepwater limestones in the GSSP of the Givetian-Frasnian boundary (Puech de la Suque, France): signals influenced by moderate diagenetic overprinting. In: DA Silva, A. C., Whalen, M. T. et al. (eds) Magnetic 
Susceptibility Application - A Window onto Ancient Environments and Climatic Variations. Geological Society, London, Special Publications, 414. First published online June 17, 2015, http://doi.org/10.1144/ SP414.15

DopieralsKa, J., BelKa, Z. \& HAACK, U. 2006. Geochemical decoupling of water masses in the Variscan oceanic system during Late Devonian times. Palaeogeography, Palaeoclimatology, Palaeoecology, 240, 108-119.

Dunlop, D. J. 2002. Theory and application of the Day plot $\left(\mathrm{M}_{\mathrm{rs}} / \mathrm{M}_{\mathrm{s}} \mathrm{v} . \mathrm{H}_{\mathrm{cr}} / \mathrm{H}_{\mathrm{c}}\right)-1$. Theoretical curves and tests using titanomagnetite data. Journal of Geophysical Research, 107, 1-22.

EGLI, R. 2003. Analysis of the field dependence of remanent magnetization curves. Journal of Geophysical Research, 108, B2, 2081, http://doi.org/10.1029/ 2002JB002023

EGLI, R. 2004. Characterization of individual rock magnetic components by analysis of remanence curves, 1. Unmixing natural sediments. Revue Studia Geophysica et Geodaetica, 48, 391-446.

Egli, R., Chen, A. P., Winklhofer, M., Kodama, K. P. \& HorNG, C. S. 2010. Detection of noninteracting single domain particles using first-order reversal curve diagrams. Geochemistry, Geophysics, Geosystems, 11, Q01Z11, http://doi.org/10.1029/2009GC 002916

EhrenberG, S. N. \& Svana, T. A. 2001. Use of spectral gamma-ray signature to interpret stratigraphic surfaces in carbonate strata: an example from the Finnmark carbonate platform (Carboniferous-Permian), Barents Sea. AAPG Bulletin, 85, 295-308.

Ellwood, B. B., Crick, R. E. \& El Hassani, A. 1999. Magnetosusceptibility event and cyclostratigraphy (MSEC) method used in geological correlation of Devonian rocks from Anti-Atlas Morocco. The American Association of Petroleum Geologists, Bulletin, 83, 1119-1134.

Ellwood, B. B., Crick, R. E., El Hassani, A., Benoist, S. L. \& Young, R. H. 2000. Magnetosusceptibility event and cyclostratigraphy method applied to marine rocks: detrital input v. carbonate productivity. Geology, 28, 1135-1138.

Ellwood, B. B., Crick, R. E., Carcia-Alcade FernanDEZ, J. L., Soto, F. M., Truyóls-Massoni, M., El Hassani, A. \& Kovas, E. J. 2001. Global correlation using magnetic susceptiblity data from Lower Devonian rocks. Geology, 29, 583-586.

Ellwood, B. B., García-Alcalde, J. L. et AL. 2006. Stratigraphy of the Middle Devonian boundary: Formal definition of the susceptibility magnetostratotype in Germany with comparisons to sections in the Czech Republic, Morocco and Spain. Tectonophysics, 418, 31-49.

Ellwood, B. B., Tomkin, J. H., Richards, B. C., Benoist, S. L. \& LAMBert, L. L. 2007. MSEC data sets record glacially driven cyclicity: examples from the arrow canyon Mississippian-Pennsylvanian GSSP and associated sections. Palaeogeography, Palaeoclimatology, Palaeoecology, 255, 377-390.

Ellwood, B. B., Tomkin, J. H., Febo, L. A. \& Stuart, Jr. C. N. 2008. Time series analysis of magnetic susceptibility variations in deep marine sedimentary rocks: a test using the upper Danian-Lower Selandian proposed GSSP, Spain. Palaeogeography, Palaeoclimatology, Palaeoecology, 261, 270-279.

Ellwood, B. B., Algeo, T. J., El Hassani, A., Tomkin, J. H. \& Rowe, H. D. $2011 a$. Defining the timing and duration of the Kačák Interval within the Eifelian/ Givetian boundary GSSP, Mech Irdane, Morocco, using geochemical and magnetic susceptibility patterns. Palaeogeography, Palaeoclimatology, Palaeoecology, 304, 74-84.

Ellwood, B. B., Tomkin, J. H. et AL. 2011b. A climatedriven model and development of a floating point time scale for the entire Middle Devonian Givetian Stage: a test using magnetostratigraphy susceptibility as a climate proxy. Palaeogeography, Palaeoclimatology, Palaeoecology, 304, 85-95.

Ellwood, B. B., Wang, W.-H., Tomkin, J. H., Ratcliffe, K. T., El Hassani, A. \& Wright, A. M. 2013. Testing high resolution magnetic susceptibility and gamma radiation methods in the Cenomanian-Turonian (Upper Cretaceous) GSSP and near-by coeval section. Palaeogeography, Palaeoclimatology, Palaeoecology, 378, 75-90.

Ellwood, B. B., El Hassani, A., Tomkin, J. H. \& Bultynck, P. 2015. A climate-driven model and development of a floating-point timescale for the middle devonian Eifelian stage using time-series analysis of magnetic susceptibility $(\chi)$ data set. In: DA SILVA, A. C., Whalen, M. T. eT AL. (eds) Magnetic Susceptibility Application - a Window onto Ancient Environments and Climatic Variations. Geological Society, London, Special Publications, 414. First published online November 21, 2014, http://doi.org/10.1144/ SP414.4

ENGLISH, L. T. P. 1999. The use of magnetic susceptibility and trace element geochemistry for the correlation of fine-grained siliciclastic sequences: a Late Llandovery example from northwest England. Geological Magazine, 136, 423-436.

Evans, M. E. \& Heller, F. 2003. Environmental Magnetism: Principles and Applications of Enviromagnetics. Academic Press, New York.

Font, E., Trinidade, R. I. F. \& Nédélec, A. 2005. Detrital remagnetization in haematite-bearing Neoproterozoic Puga cap dolostone, Amazon craton: a rock magnetic and SEM study. Geophysical Journal International, 163, 491-500.

Font, E., Nascimento, C., Omira, R., Baptista, M. A. \& Silva, P. F. 2010. Identification of tsunami-induced deposits using numerical modeling and rock magnetism techniques: a study case of the 1755 Lisbon tsunami in Algarve, Portugal. Physics of the Earth and Planetary Interiors, 182, 187-198.

Foubert, A. \& Henriet, J. P. 2009. Nature and Significance of the Recent Carbonate Mound Record. The Mound Challenger Code. Springer, Berlin, Lecture Notes in Earth Sciences, 126.

FranK, M. 2002. Radiogenic isotopes: tracers of past ocean circulation and erosional input. Reviews of Geophysics, 40, 1-1-1-38.

García-Alcalde, J. L., Ellwood, B. B., Soto, F., Truyóls-Massoni, M. \& Tomkin, J. H. 2012. Precise timing of the Upper Taghanic Biocrisis, Geneseo Bioevent, in the Middle-Upper Givetian 
(Middle Devonian) boundary in Northern Spain using biostratigraphic and magnetic susceptibility data sets. Palaeogeography, Palaeoclimatology, Palaeoecology, 313-314, 26-40.

GerŠL, M. \& HLADIL, J. 2004. Gamma-ray and magnetic susceptibility correlation across a Frasnian carbonate platform and the search for 'punctata' equivalents in stromatoporoid-coral limestone facies of Moravia. Geological Quarterly, 48, 283-292.

GrabowsKi, J., Schnyder, J. ET AL. 2013. Magnetic susceptibility and spectral gamma logs in the TithonianBerriasian pelagic carbonates in the Tatra Mts (Western Carpathians, Poland): palaeoenvironmental changes at the Jurassic/Cretaceous boundary. Cretaceous Research, 43, 1-17.

Grabowski, J., Narkiewicz, M. \& De Vleeschouwer, D. 2015. Forcing factors of the magnetic susceptibility signal in lagoonal and subtidal depositional cycles from the Zachełmie section (Eifelian, Holy Cross Mountains, Poland). In: Da Silva, A. C., Whalen, M.T. ETAL. (eds) Magnetic Susceptibility Application A Window onto Ancient Environments and Climatic Variations. Geological Society, London, Special Publications, 414. First published online February 6, 2015, http://doi.org/10.1144/SP414.5

Hinnov, L. A. \& Hilgen, F. J. 2012. Chapter 4 - cyclostratigraphy and astrochronology. In: GradSTEIN, F. M., OGG, J. G., Schmitz, M. \& OGG, G. The Geologic Time Scale. Elsevier, Boston, MA, 63-83.

HLADIL, J. 2002. Geophysical records of dispersed weathering products on the Frasnian carbonate platform and early Famennian ramps in Moravia, Czech Republic: proxies for eustasy and palaeoclimate. Palaeogeography, Palaeoclimatology, Palaeoecology, 181, 213-250.

Hladil, J., Slavik, L., Carew, J. L., Mylroie, J. E. \& GERSL, M. 2003. Early diagenetic origin and persistence of gamma-ray and magnetosusceptibility patterns in platform carbonates: comparison of Devonian and Quaternary sections. Physics and Chemistry of the Earth, 28, 719-727.

Hladil, J., Carew, J. L. ET AL. 2004. Anomalous magnetic susceptibility values and traces of subsurface microbial activity in carbonate banks on San Salvador Island, Bahamas. Facies, 50, 161-182.

Hladil, J., Gersl, M., Strnad, L., Frana, J., Langrova, A. \& SPISIAK, J. 2006. Stratigraphic variation of complex impurities in platform limestones and possible significance of atmospheric dust: a study with emphasis on gamma-ray spectrometry and magnetic susceptibility outcrop logging (Eifelian-Frasnian, Moravia, Czech Republic). International Journal of Earth Science, 95, 703-723.

Hladil, J., Koptikova, L. ET AL. 2009. Early Middle Frasnian platform reef strata in the Moravian Karst interpreted as recording the atmospheric dust changes: the key to understanding perturbations in the punctata conodont Zone. Bulletin of Geosciences, 84, 75-106.

Hladil, J., Cejchan, P., Babek, O., Koptikova, L., Navratil, T. \& Kubinova, P. 2010a. Dust - a geology-orientated attempt to reappraise the natural components, amounts, inputs to sediment, and importance for correlation purposes. Geologica Belgica, 13, 367-384.
Hladil, J., Vondra, M., Cejchan, P., Vich, R., Koptikova, L. \& SlaviK, L. 2010b. The dynamic time-warping approach to comparison of magnetic-susceptibility logs and application to lower Devonian calciturbidites (Prague Synform, Bohemian Massif). Geologica Belgica, 13, 385-406.

Hounslow, M. W. \& MAHER, B. A. 1999. Laboratory procedures for quantitative extraction and analysis of magnetic minerals from sediments. In: WALDEN, J., Oldfield, F. \& SMith, J. (eds) Environmental Magnetism, a Practical Guide. Quaternary Research Association, London, Technical Guides, 139-164.

Jackson, M., Rochette, P., Fillion, G., Banerjee, S. \& Marvin, J. 1993. Rock magnetism of remagnetized Palaeozoic carbonates: low-temperature behavior and susceptibility characteristics. Journal of Geophysical Research, 98, 6217-6225.

JADOT, H. \& Boulvain, F. 2015. Sedimentology and magnetic susceptibility of recent sediments from New Caledonia. In: DA Silva, A. C., Whalen, M. T. ET AL. (eds) Magnetic Susceptibility Application - A Window onto Ancient Environments and Climatic Variations. Geological Society, London, Special Publications, 414. First published online February 6, 2015, http://doi.org/10.1144/SP414.2

Kirschvink, J. L. \& CHANG, S. B. R. 1984. Ultrafinegrained magnetite in deep-sea sediments: possible bacterial magnetofossils. Geology, 12, 559-562.

Kopp, R. E. \& KirschvinK, J. L. 2008. The identification and biogeochemical interpretation of fossil magnetotactic bacteria. Earth-Science Reviews, 86, 42-61.

Koptíková, L. 2011. Precise position of the Basal Choteč event and evolution of sedimentary environments near the Lower-Middle Devonian boundary: the magnetic susceptibility, gamma-ray spectrometric, lithological, and geochemical record of the Prague Synform (Czech Republic). Palaeogeography, Palaeoclimatology, Palaeoecology, 304, 96-112.

Koptíková, L., BábeK, O., Hladil, J., Kalvoda, J. \& SLAVÍK, L. 2010a. Stratigraphic significance and resolution of spectral reflectance logs in Lower Devonian carbonates of the Barrandian area, Czech Republic; a correlation with magnetic susceptibility and gamma-ray logs. Sedimentary Geology, 225, 83-98.

Koptíková, L., Hladil, J., Slavík, L., Čejchan, P. \& BÁBEK, O. 2010b. Fine-grained non-carbonate particles embedded in neritic to pelagic limestones (Lochkovian to Emsian, Prague Synform, Czech Republic): composition, provenance and Links to magnetic susceptibility and gamma-ray logs. Geologica Belgica, 13, 407-430.

KozŁowski, W. \& SobIeń, K. 2012. Mid-Ludfordian coeval carbon isotope, natural gamma ray and magnetic susceptibility excursions in the Mielnik IG-1 borehole (Eastern Poland) - dustiness as a possible link between global climate and the Silurian carbon isotope record. Palaeogeography, Palaeoclimatology, Palaeoecology, 339-341, 74-97.

Kruiver, P. P., DekKers, M. J. \& Heslop, D. 2001. Quantification of magnetic coercivity components by the analysis of acquisition curves of isothermal remanent magnetisation. Earth and Planetary Science Letters, 189, 269-276. 
Mabille, C. \& Boulvain, F. 2007. Sedimentology and magnetic susceptibility of the Upper EifelianLower Givetian (Middle Devonian) in SW Belgium: insights into carbonate platform initiation. In: Alvaro, J. J., Aretz, M., Boulvain, F., Munnecke, A., Vachard, D. \& Vennin, E. (eds) Palaeozoic Reefs and Bioaccumulations: Climatic and Evolutionary Controls. Geological Society, London, Special Publications, 275, 109-123.

Mabille, C. \& Boulvain, F. 2008. Les Monts de Baileux section: detailed sedimentology and magnetic susceptibility of Hanonet, Trois-Fontaines and Terres d'Haurs Formation (Eifelian/Givetian boundary and Lower Givetian, SW Belgium). Geologica Belgica, 11, 93-121.

Mabille, C., Pas, D., Aretz, M., Boulvain, F., SchröDER, S. \& DA Silva, A. C. 2008. Deposition within the vicinity of the Mid-Eifel High: detailed sedimentological study and magnetic susceptibility of a mixed ramp-related system from the Eifelian Lauch and Nohn Formations (Ohlesberg, Eifel, Germany) Facies, 54, 597-612.

MaHer, B. A. 2011. The magnetic properties of Quaternary aeolian dusts and sediments, and their palaeoclimatic significance. Aeolian Research, 3, 87-144.

Mayrhofer, S. \& Lukeneder, A. 2015. Susceptibility and radiometry data used for stratigraphic correlations: case study on Upper Triassic beds in Turkey. In: DA Silva, A. C., Whalen, M. T. et AL. (eds) Magnetic Susceptibility Application - A Window onto Ancient Environments and Climatic Variations. Geological Society, London, Special Publications, 414. First published online April 1, 2015, http://doi.org/10.1144/ SP414.10

Mead, A. G. \& TAuxe, L. 1986. Oligocène Paleoceanography of the South Atlantic: paleoclimatic implications of sediment accumulation rates and magnetic susceptibility measurements. Paleoceanology, 1, 273-284.

Meyers, S. R. \& Sageman, B. B. 2007. Quantification of deep-time orbital forcing by average spectral misfit. American Journal of Science, 307, 773-792.

Michel, J., Boulvain, F., PhilipPo, S. \& Da Silva, A. C. 2010. Palaeoenvironmental study and small scale correlations using facies analysis and magnetic susceptibility of the mid-Emsian (Himmelbaach quarry, Luxembourg). In: DA Silva, A. C. \& Boulvain, F. (eds) Magnetic Susceptibility, Correlations and Palaeozoic Environments. Geologica Belgica, 13, 447-458.

Mullins, C. E. \& Tite, M. S. 1973. Magnetic viscosity,quadrature susceptibility, and frequency dependence of susceptibility in single-domain assemblies of magnetite and maghemite. Journal of Geophysic Research, 78, 804-809.

Nawrocki, J., Polechonska, O. \& Werner, T. 2008. Magnetic susceptibility and selected geochemicalmineralogical data as proxies for Early to Middle Frasnian (Late Devonian) carbonate depositional settings in the Holy Cross Mountains, southern Poland. Palaeogeography, Palaeoclimatology, Palaeoecology, 269, $176-188$

Oldfield, F., Dearing, J. A., Thompson, R. \& GarrettJoNES, S. E. 1978. Some magnetic properties of lake sediments and their possible links with erosion rates. Polskie Archiwum Hydrobiologii, 25, 321-331.

PARRY, L. G. 1982. Magnetization of immobilized particle dispersions with two distinct particles sizes. Physics of the Earth and Planetary interiors, 28, 230-241.

Pas, D., DA Silva, A. C. ET AL. 2015. Sedimentary development and magnetic susceptibility evolution of the Frasnian carbonate platform in Western Belgium (Dinant Synclinorium, La Thure section). In: DA Silva, A. C., Whalen, M. T. ET AL. (eds) Magnetic Susceptibility Application - A Window onto Ancient Environments and Climatic Variations. Geological Society, London, Special Publications, 414. First published online December 8, 2014, http://doi.org/10. 1144/SP414.7

Racki, G., Racka, M., Matyja, H. \& Devleeschouwer, X. 2002. The Frasnian/Famennian boundary interval in the South Polish-Moravian shelf basins: integrated event-stratigraphical approach. Palaeogeography, Palaeoclimatology, Palaeoecology, 181, 251-297.

Radhakrishnamurty, C., Likhite, S. D., Amin, B. S. \& Somayajulu, B. L. K. 1968. Magnetic susceptibility stratigraphy in ocean sediment cores. Earth and Planetary Science Letters, 4, 464-468.

Rey, D., Rubio, B., Mohamed, K., Vilas, F., Alonso, B., Ercilla, G. \& Rivas, T. 2008. Detrital and early diagenetic processes in Late Pleistocene and Holocene sediments from the SW Galicia Bank inferred from high-resolution enviromagnetic and geochemical records. Marine Geology, 249, 64-92.

Riquier, L., Averbuch, O., Devleeschouwer, X. \& Tribovillard, N. 2010. Diagenetic v. detrital origin of the magnetic susceptibility variations in some carbonate Frasnian-Famennian boundary sections from Northern Africa and Western Europe: implications for paleoenvironmental reconstructions. International Journal of Earth Sciences, 99, S57-S73.

Roberts, A. P., Pike, C. R. \& Verosub, K. L. 2000. First-order reversal curve diagrams: a new tool for characterizing the magnetic properties of natural samples. Journal of Geophysical Research, 105, 28461-28475.

Roberts, A. P., Liu, Q., Rowan, C. J., Chang, L., Carvallo, C., Torrent, J. \& Horng, C. S. 2006. Characterization of hematite $\left(\alpha-\mathrm{Fe}_{2} \mathrm{O}_{3}\right)$, goethite $(\alpha-\mathrm{FeOOH})$, greigite $\left(\mathrm{Fe}_{3} \mathrm{~S}_{4}\right)$, and pyrrhotite $\left(\mathrm{Fe}_{7} \mathrm{~S}_{8}\right)$ using firstorder reversal curve diagrams. Journal of Geophysical Research: Solid Earth, 111, B12S35, http://doi.org/ 10.1029/2006JB004715

Robertson, D. J. \& France, D. E. 1994. Discrimination of remanence-carrying minerals in mixtures, using isothermal remanent magnetisation acquisition curves. Physics of the Earth and Planetary interiors, 82, 223-234

RobInson, S. G. 1986. The late Pleistocene palaeoclimatic record of North Atlantic deep-sea sediments revealed by mineral-magnetic measurements. Physics of the Earth and Planetary interiors, 42, 22-47.

Rodionov, V. P., DeKKers, M. J., Khramov, A. N., Gurevich, E. L., Krijgsman, W., Duermeijer, C. E. \& Heslop, D. 2003. Paleomagnetism and cyclostratigraphy of the Middle Ordovician Krivolutsky suite, Krivaya Luka section, southern Siberian platform: record of non-synchronous NRM-components or a 
non-axial geomagnetic field? Studia Geophysica Geodaetica, 47, 255-274.

Sardar Abadi, A., Da Silva, A. C., Mossadegh, H., Spassov, S. \& Boulvain, F. 2015. Lower Carboniferous ramp sedimentation of the Central Alborz Basin, northern Iran: integrated sedimentological and rockmagnetic studies. In: Da Silva, A. C., Whalen, M. T. ET AL. (eds) Magnetic Susceptibility Application - A Window onto Ancient Environments and Climatic Variations. Geological Society, London, Special Publications, 414. First published online May 26, 2015, http://doi.org/10.1144/SP414.13

Shackleton, N. J., Crowhurst, S. J., Weedon, G. P. \& LASKAR, J. 1999. Astronomical calibration of Oligocene-Miocene time. Philosophical Transactions of the Royal Society of London. Series A: Mathematical, Physical and Engineering Sciences, 357, 1907-1929.

Śliwiński, M. G., Whalen, M. T., Meyer, F. J. \& Majs, F. 2012. Constraining clastic input controls on magnetic susceptibility and trace element anomalies during the Late Devonian punctata Event in the Western Canada Sedimentary Basin. Terra Nova, 24, 301-309.

Spassov, S. \& VAlet, J. P. 2012. Detrital magnetizations from redeposition experiments of different natural sediments. Earth and Planetary Science Letters, 351-352, 147-157.

Stage, M. 2001. Magnetic susceptibility as carrier of a climatic signal in chalk. Earth and Planetary Science Letters, 188, 17-27.

TAuXe, L. 2010. Essentials of Paleomagnetism. University of California Press, Berkeley.

Tauxe, L., Bertam, H. N. \& Seberino, C. 2002. Physical interpretation of hysteresis loops: micromagnetic modeling of fine particle magnetite. Geochemistry, Geophysics, Geosystems, 3, 1-22.

Tite, M. S. \& Linington, R. E. 1975. Effect of climate on the magnetic susceptibility of soils. Nature, $\mathbf{2 5 6}$, $565-566$

Tribovillard, N., Algeo, T. J., Lyons, T. \& RiboulLEAU, A. 2006. Trace metals as paleoredox and paleoproductivity proxies: An update. Chemical Geology, 232, 12-32.

Walden, J., Oldfield, F. \& Smith, J. 1999. Environmental Magnetism: a Practical Guide. Quaternary Research Association, London, Technical Guides, 6, $1-244$.

Whalen, M. T. \& Day, J. 2008. Magnetic susceptibility, biostratigraphy and sequence stratigraphy: insights into Devonian carbonate platform development and basin infilling, Western Alberta, Canada. In: Controls on Carbonate Platform and Reef Development. Society of Economic Paleontologists and Mineralogists, Tulsa, OK, Special Publications, 89, 291-314.

Whalen, M. T. \& DAY, J. 2010. Cross-basin variations in magnetic susceptibility influenced by changing sea level, paleogeography, and paleoclimate: upper Devonian, Western Canada. Journal of Sedimentary Research, 80, 1109-1127.

Whalen, M. T., Sliwinski, M. G., Payne, J. H., Day, J. E., Chen, D. \& DA Silva, A. C. 2015. Chemostratigraphy and magnetic susceptibility of the Late Devonian Frasnian-Famennian transition in western Canada and southern China: implications for carbon and nutrient cycling and mass extinction. In: DA Silva, A. C., Whalen, M. T. ET AL. (eds) Magnetic Susceptibility Application - a Window onto Ancient Environments and Climatic Variations. Geological Society, London, Special Publications, 414. First published online February 9, 2015, http://doi.org/10. $1144 /$ SP414.8

Zhang, S., WANG, X. \& ZHU, H. 2000. Magnetic susceptibility variations of carbonates controlled by sea level changes - examples in Devonian to Carboniferous strata in southern Guizhou Province, China. Science in China, Series D, 43, 266-276.

Zwing, A., Matzka, J., Bacvhtadse, V. \& Soffel, H. C. 2005. Rock magnetic properties of remagnetized Palaeozoic clastic and carbonate rocks from the NE Renish massif, Germany. Geophysical Journal International, 160, 477-486. 